\title{
Characteristic of nicotine delivery devices - electronic cigarettes - as a tool to fight against tobacco dependence
}

\author{
A. Ye. Bogomolov \\ National Pirogov Memorial Medical University, Vinnytsia, Ukraine
}

The aim of the study is the analysis of specialized scientific literature and the review of data about the modern views on the electronic devices of nicotine delivery - electronic cigarettes from the view of evidence-based medicine. In recent years, electronic cigarettes (EC) have become widespread. More than 10 years have passed since the first batch release of electronic cigarettes, and during that time, many studies have been conducted on various aspects of their use. However, the main concern of experts is the lack of a clear unanimous opinion about their health security and the EC's effectiveness as a method of tobacco control. The review presents modern data regarding existing EC modifications, the impact of their use on the human body at the cellular and systemic levels. Attention is paid to the fact that the actual physical nicotine dependence in the vast majority of cases is combined with psychological dependence, which reduces the effectiveness of other nicotine delivery devices. Data from randomized clinical trials show that further development of methods for studying the effects of the EC on the organism is very actual. In general, such studies were made to highlight key issues regarding the safety and effectiveness of e-cigarette use, including the fight against tobacco smoking. Special cautions were made to the research results that indicate the growing of popularity of e-cigarettes among teenagers, particularly in the US, Poland, Latvia, Finland and Korea.

Conclusions. The EC has proven to be effective in removing of tobacco-related complaints, but so far, the EC cannot be available as safe and effective method to completely abandon smoking. Existing production regulations do not standardize either the EC itself or the liquid for them, because of which the composition (including the content of harmful to health substances) is not actually regulated. In addition, there are no data about the long-term effects of EC usage, which is a priority area for further research.

\section{Характеристика пристроїв доставки нікотину - електронних сигарет - як засобу боротьби із тютюновою залежністю}

\section{А. Є. Богомолов}

Мета роботи - аналіз спеціалізованої наукової літератури для узагальнення даних про сучасні погляди на пристрої доставки нікотину - електронні сигарети - в аспекті доказової медицини.

Електронні сигарети (EC) набули широкої популярності, виокремившись навіть в окрему «субкультуру». Минуло понад 10 років із часу першого серійного випуску електронних сигарет, і вже здійснено чимало досліджень різних аспектів їх використання. Основну стурбованість експертів викликає відсутність єдиної думки щодо їхньої безпеки для здоров'я та власне ефективності ЕС як методу боротьби з тютюнопалінням. Наведені сучасні уявлення про модифікації ЕС, вплив їх вживання на організм людини на клітинному та системному рівнях. Звертається увага, що власне фізична нікотинова залежність збедільшого поєднується з психологічною, що знижує ефективність інших пристроїв доставки нікотину. Дані, що отримані в рандомізованих клінічних дослідженнях, показують: необхідність розробки методів дослідження впливу ЕС на організм є все актуальною. В основному такі дослідження полягають у висвітленні основних питань щодо безпечності та ефеективності застосування ЕС, зокрема в боротьбі з тютюнопалінням. Особливої настороги потребують результати досліджень, що вказують на ріст популярності ЕС серед підлітків, зокрема у США, Польщі, Латвії, Фінляндії та Кореї.

Висновки. ЕС виявились ефективними в усуненні скарг, пов'язаних із тютюнопалінням, однак поки що їх не можна розглядати як безпечні та ефективні засоби для повної відмови від паління. Чинні регламенти виробництва не стандартизують ані самі EC, ані рідини для них, через що склад (у тому числі вміст шкідливих для здоров'я домішок) фрактично не регламентується. Відсутні дані про віддалені наслідки вживання ЕС, що є пріоритетним напрямом наступних досліджень.

\section{Характеристика приборов доставки никотина - электронных сигарет - как способа борьбы с табачной зависимостью}

\section{А. Е. Богомолов}

Цель работы - анализ специализированной научной литературы для обобщения данных о современных взглядах на устройства доставки никотина - электронные сигареты - с точки зрения доказательной медицины.

Электронные сигареты (ЭС) получили широкое распространение, выделившись даже в отдельную «субкультуру». Прошло более 10 лет с момента первого серийного выпуска электронных сигарет, и за это время проведено немало исследований по различным аспектам их использования. Основную обеспокоенность экспертов вызывает отсутствие единого мнения по поводу их безопасности для здоровья и собственно эффективности ЭС как метода борьбы с табакокурением. Представлены современные взгляды на существующие модификации ЭС и влияние их применения на организм человека на клеточном и системном уровнях. Обращается внимание, что собственно физическая никотиновая зависимость в большинстве случаев сочетается с психологической, что снижает эффективность других
Key words:

electronic nicotine delivery systems, nicotine, tobacco use disorder, youth, vaping.

Zaporozhye medical journal 2018; 20 (2), 275-279 DOI: 10.14739/2310-1210 2018.2.125528

E-mail: art.bogomolov@ gmail.com

Киючові слова: електронні системи Аоставки нікотину, нікотин, боротьба з тютюновою залежністю, психологічна залежність віА паління, молодь, вейпінг.

Запорізький медичний журнал. - 2018. T. 20, № 2(107). C. 275-279 
устройств доставки никотина. Данные, полученные в рандомизированных клинических исследованиях, показывают, что необходимость разработки методов исследования влияния ЭС на организм является все более актуальной. В основном такие исследования заключаются в освещении основных вопросов безопасности и эффективности применения электронных сигарет, в том числе в борьбе с табакокурением. Особой настороженности требуют результаты исследований, которые указывают на рост популярности электронных сигарет среди подростков в США, Польше, Латвии, Финляндии и Корее.

Выводы. ЭС оказались эффективными в устранении жалоб, связанных с табакокурением, однако пока они не могут рассматриваться как безопасные и эффективные средства для полного отказа от курения. Существующие регламенты производства не стандартизируют ни сами ЭС, ни жидкости для них, из-за чего состав (в том числе и содержание вредных для здоровья примесей) фрактически не регламентируется. Кроме того, отсутствуют данные о долговременных последствиях употребления ЭС, что является приоритетным направлением исследований.

The fight against tobacco addiction today is an important medical and social problem. It is connected not only with the prevalence of tobacco smoking among the population (prevalence of daily smoking among the residents of Ukraine over 18 years old is $24 \%$, particularly among women $9.0 \%$ and among men $-42.4 \%$ - by the 2015 ), but with its impact on the health of both the smoker and the people around him.

Despite the active anti-tobacco companies, about 11.5 million of Ukrainians part of their pensions, salaries and scholarships are spending on cigarettes. Active smokers are about one third of young people aged 18 to 25 years, and each second addicted on tobacco tried his first cigarette before the age of 12 years old. In Ukraine, tobacco smoking is indirectly the cause of death of people aged over 35 years in every fifth case [1].

However, about $80 \%$ of smokers in Ukraine have expressed the desire to quit [2], but only some of them actually starts their own struggle with addiction and achieves success even smaller percentage of smokers. Unsuccessful attempts to abandon tobacco-related factors and a considerable number of reasons, ranging from the social environment itself and ending dependence on nicotine as a body chemical. In compensation for the actual physical dependence on nicotine directed a number of methods for replacement / delivery of nicotine, which includes nicotine patches, chewing gum, tablets, solutions and electronic devices of nicotine delivery (EDND). Last years the group of EDND and electronic cigarettes as typical representatives of this group has become so widespread among the population of the world, that WHO presented a report on EDND during the Sixth session of the Conference of the Parties on the WHO Framework Convention on Tobacco Control (13-16.10.2014).

The aim of the study is the analysis of specialized scientific literature and the review of data about the modern views on the electronic devices of nicotine delivery - electronic cigarettes from the view of evidence-based medicine. It should be noted that it is more than 10 years since the first mass production of electronic cigarettes and during this time a lot of research conducted on various aspects of their use. However, the main concern of the experts is the lack of a clear consensus on their safety for health and efficacy of EDND as a method to combat smoking. At the same time, on the background of such uncertainty thoughts e-cigarettes are becoming increasingly popular in the world and in particular in Ukraine. Thus, a whole social group of people who call themselves "vapers" (from the English "vapor") was formed, and the process of "smoking" they named "vaping". Among the major countries usage of these devices fall on China, the US and some EU countries; on the other hand their use is prohibited in Brazil, Canada, Denmark, Turkey, Norway, Australia, Uruguay and Jordan. The rules of e-cigarettes usage are regulated by law in our country; particularly the Law of Ukraine "About the Measures to prevent and reduce tobacco use and its harmful effects on health" prohibits the use of these devices in public places [3]. Thus today in Ukraine there is no research that would be dedicated to e-cigarettes. Logically, awareness of Ukrainian doctors on this issue is therefore low and this means that they may not be able to provide adequate advice to a patient asking about the topic. On the other hand, the lack of clinical research leads to the lack of uniform standards for the manufacturers and importers of e-cigarettes, which, in turn, contributes to a large number of irregularities and fraud real composition of fluids that indicated on the package. Thus, Japanese researchers found in several samples of fluid for electronic cigarettes high amounts of formaldehyde and acetaldehyde, and British BBC journalist during its own investigation in one of the fluids found diacetyl, which is a powerful carcinogenic substance. In addition, the lack of regulations and standards is leading to significant difficulties of the implementation of the law prohibiting the use of public places, because the fact the definition of electronic cigarette in it missing.

Before we review the current state of research on e-cigarettes in the world literature, it is advisable to turn to the history of invention and improvement of these products. The first prototype of the e-cigarette was designed in 1963 by Herbert Gilbert. The unit produced pairs of tobacco flavor, but without nicotine. However, while the invention was not relevant, smoking was popular and the fight against it and its negative consequences not stand so badly. Because of his invention never gained recognition and did not apply [4]. And in 2003, China researcher Hon Lick was invented e-cigarettes, so they are in the present [5]. His goal was to create a device that could completely or at least partially protect smokers and others from the pernicious effects of tobacco smoke, ideally, such an agent would help get rid of tobacco dependence. For example, researchers successfully combined nicotine and propylene glycol and added flavoring additives, recreating the taste of cigarettes and creating simulated smoking. The first drawing device e-cigarette dispenser appeared in April 2003 and was immediately patented. A year later the company "Golden Dragon Holding" was released the first example of the device after a few months already released a full batch of e-cigarettes. Over time, they were improved, became lighter, smaller and more convenient, there were new tastes and flavors. E-cigarettes are rapidly gained popularity around the world. 
In America, the invention won several awards; gradually e-cigarettes have appeared in other countries, began to gain market and manufactured various models of these products [6].

Currently e-cigarettes have gained considerable spread in the world. Their output is involved in more than 450 different brands. Sales volumes of e-cigarettes for 2014 amounted to 795 million dollars in the US, which corresponds to 19.6 million units of production [7]. In the world the amount of sales in 2014 reached 2.475 billion. Total number of e-cigarette smokers is now about 45 million, and the percentage of adults who used e-cigarettes is currently $6.7 \%$ of the world; among the high school students it is $10 \%$. The percentage of people who quit smoking after switching to e-cigarettes for 6 months is $31 \%$ [8].

It has a simple design, the main elements of which are: battery, electronic dispenser sprayer (heating device atomizer), the management electronics for the container of liquid pairing (capsules, cartridges) and smoke bombs (optional) [9]. Many manufacturers produce different accessories like USB charger, car charger, carrying pouch. Management electronics can be implemented based on a microprocessor with a switch in one of three designs: depending on the model, this is the vacuum sensor for detecting airflow, acoustic switch or manual as a button. Smoke bombs (mini-cigarettes) are replaceable cartridge filled with a special liquid that contains propylene glycol (from $50 \%$ to $99.6 \%$ ), vegetable glycerin, nicotine (from $0 \%$ to $3.6 \%$ ), and aromatic additives. The cartridge has two holes: one for the steam, the other - to receive electricity from the battery or the connection to the spray. The composition of liquids for e-cigarettes typically include: distilled water, food additive E1520 - propylene glycol; food additive E422 - glycerol; nicotine. It is possible to use in the liquid for smoking and other ingredients, antioxidants, organic acids and others. The composition of the liquid varies depending on the manufacturer, often are: propylene glycol (54.4\%), nicotine $(0.6 \%)$, vegetable glycerin $(35.0 \%)$, distilled water $(10.0 \%)$. Liquids can contain different amounts of nicotine. Information about the concentration of nicotine in the liquid for steaming is made print on the bottle or cartridge and a standard notation "mg/ml". Cartridges or liquid fall on the content of nicotine in the liquid to following: without nicotine ( $0 \mathrm{mg} / \mathrm{ml}$ ), super lightweight ( 1 to $9 \mathrm{mg} / \mathrm{ml}$ ), lightweight (10 to $13 \mathrm{mg} / \mathrm{ml})$, strong (13-18 mg/ml), very strong (19-36 mg/ml) [10]. This one regular cigarette contains on average $0.8 \mathrm{mg}$ nicotine, and one full acceptance of electronic cigarettes (from first to last puffs in one consumption) consumed an average of $0.1 \mathrm{ml}$ of fluid [11]. In an amount 0.1 * contains $16 \mathrm{mg} / \mathrm{ml}=1.6 \mathrm{mg}$ nicotine (for example consumption of light taken cartridges). At first glance it is 20 times the dose of nicotine in one cigarette. However, revealed that after the use of conventional cigarette nicotine level in the blood raises an average of $15 \mathrm{ng} / \mathrm{mL}$, while after using electronic cigarettes $-1.5 \mathrm{ng} / \mathrm{ml}$ - ten times less. That is the real number of consumed nicotine in the use of e-cigarettes will be: $1.6 / 10=0.16 \mathrm{mh}$. This is $0.8 / 0.16=5-$ five times less nicotine than smoking ordinary cigarettes [12]. However, in recent years began to appear in the literature data suggest some impropriety of such comparisons because of the use in the production of liquid nicotine, which is faster and more fully absorbed than the natural nicotine cigarettes.
Current studies of e-cigarettes in the world are growing in magnitude. In general, such studies are aimed to highlight the main issues regarding the safety and efficacy of e-cigarettes, including in the fight against smoking.

Obviously, especially noteworthy is to research results of motives switching to e-cigarettes. Thus, in their study, K. Angus and G. Hastings showed that $95 \%$ of respondents indicated that they believe e-cigarettes are less harmful to health, $93 \%$ - cheaper, cleaner - $95 \%$ (relative to the environment and others), $76 \%$ said they do not cause passive smoking, $73 \%$ that they are newer and trendier [13]. Speaking about the prevalence of e-cigarettes in Europe and the world is worth noting that since 2008; currently it has increased at least twice. The percentage of people who claim that tried to use e-cigarettes, about $7 \%$ in Europe and the US [14]. Other studies also show that the majority (72\%) of e-cigarette users were smokers of traditional cigarettes previously [15]. Moreover, other research results indicate the growing popularity of e-cigarettes among teenagers, particularly in the US, Poland, Latvia, Finland and Korea. Thus, in 2012, $20.3 \%$ of university students and $7.2 \%$ of high scholars reported usage of e-cigarettes, while never previously using regular cigarettes [16]. Even more attention should be paid to the fact that teenagers who tried e-cigarettes while before never used traditional, then with a much higher probability of starting to it and switched to regular cigarettes [17].

At the same time the effects of e-cigarettes on the human body are actively investigated. Among them, special attention should be paid to ingredient propylene glycol. Recent studies indicate that this substance causes irritation of the eyes, and prolonged and continuous usage causes problems of the central nervous system, behavior, affect the performance of the spleen. In addition, propylene glycol converted to propylene oxide, and this substance in turn is a class $2 \mathrm{~B}$ carcinogen, glycerol also forms acrolein, which causes irritation of the upper respiratory tract [18]. It was found that e-cigs have a powerful booster effect on phase-I carcinogen-bioactivating enzymes, including activators of polycyclic aromatic hydrocarbons (PAHs), and increase oxygen free radical production and DNA oxidation to 8-hydroxy-2'-deoxyguanosine. Furthermore, we found that e-cigs damage DNA not only at chromosomal level in peripheral blood, such as strand breaks in leucocytes and micronuclei formation in reticulocytes, but also at gene level such as point mutations in urine. The results demonstrate that exposure to e-cigs could endanger human health, particularly among younger more vulnerable consumers.

The latest data actively being discussed the effects of e-cigarettes on the cellular level. It was found that they have an impact similar to usual cigarettes to alveoli in rats. In a recent American scientists S. Chen, K. Schweitzer et al. study the impact of a couple of e-cigarettes to epithelial monolayer was revealed its destruction, and that e-cigarettes cause inflammatory effects and oxidative stress in rats [19]. Research of scientists T. Sussan, S. Gajghate, R. Thimmulappa et al. shows a decrease in lung defense against bacteria and viruses in rats on the background of the usage of e-cigarettes [20].

At the level of the organism has been shown that e-cigarettes cause effects such as an increase in diastolic blood pressure and heart rate, significant increase in 
the concentration of carboxyhemoglobin in the blood that is associated with the content of carbon monoxide in a pair of e-cigarettes [21]. It was also found that after receiving the e-cigarette indicators such as breathing resistance and airway conductance were not significantly affected [22]. However, the survey partsiv referred to the e-cigarettes were noted after the usual complaints such as dry cough, sore throat, respiratory superficiality. There have been recorded cases of clinical lipid pneumonia, atrial fibrillation and even death in people who use e-cigarettes [23].

Since that many clinical studies try to answer the question of whether the actual e-cigarettes help in the fight against tobacco. It is known that during smoking the smoker enjoys not only from receiving nicotine, but also on the process, taste, visual, tactile sensations. Therefore, the refusal of smoking the smoker is faced not only with the need for nicotine and the psychological and addiction. The unique method of e-cigarettes is that their use is simulated smoking process. This helps ease the psychological difficulties smoke-free [24].

However, if we talk about e-cigarettes in terms of combating tobacco, you will notice the lack of reliable data efficiency in the fight against nicotine addiction. Instead, there is evidence that this is denied, in particular, refers to a strong psychological dependence on e-cigarettes. For most people believe e-cigarettes are completely safe, because over time they cannot eliminate these devices, and as a result has not cured from nicotine addiction, and often consume even higher doses of nicotine than previously [25]. The research group of people who had tobacco addiction does not have health problems, show more expressed effects of e-cigarettes compared with placebo (placebo $4 \%$ compared to e-cigarettes $9 \%$; 2 studies; reliability is low) and e-cigarettes compared to the nicotine patch (nicotine patches (44\%) compared with e-cigarettes $(61 \%)$; reliability - very low) while eliminating tobacco dependence [26].

While studies of people with uncompensated heart disease in Onanis center of cardiac surgery showed that $81 \%$ of surveyed gave up smoking habit by using e-cigarettes, with a significant portion longer use conventional cigarettes at the first month of the experiment [2]. However, there apparently was the motivation for this failure and ascribe merit only e-cigarette is not completely correct.

Among healthy people completely abandon conventional cigarettes when switching to e-cigarettes only $18 \%$, US researchers have shown that $A$. Wilson, $G$. Mnatzaganian, N. Hann et al. [27]. In the study conducted at Wingate University scientists R. Waghel, D. Battise, M. Ducker et al. said that reducing the number of conventional cigarettes, which are used by train the day was observed in $50 \%$ of studied [28].

Thus, the study illustrate the apparent lack of consistency and integrity of scientists and doctors thought about the safety of e-cigarettes and efficiency EPDN for actual combat smoking. Currently, research on this topic is relevant, but this does not exclude the difficulties and problems that may arise. The issue of further research and steps the medical community obviously has to have several major areas. First of all perspectives are considered long-term study of the effects of these devices is not currently possible because of the relative novelty EPDN. You'll also need clear regulation of health, technological and medical standards development and use of electronic cigarettes currently actively considered at a committee of leading countries.

This can be noted qualitatively positive aspects of the subject of research in the world. This above all: real addresses of attention and coverage problems at major conferences, conventions pulmonologists, including the European Respiratory Society and the 16-th World Conference WHO. Also subject actively studied at the cellular level, allowing you to better understand the biochemical and physiological effects of the use of e-cigarettes. The positive dynamics of growth of the number of people who use e-cigarettes also provides more space for the observation of the effects of these devices. Of course, it should be noted options and increase research methods devices.

In Ukraine, in turn, the main problem of this topic study is that currently there are no any studies on e-cigarettes. This is probably one reason for low awareness of doctors and the lack of a clear opinion on the matter. Noteworthy and the lack of any hygiene standards in Ukraine for these devices, and as a result, a large number of substandard products in the market, the actual chemical composition of which cannot meet the specified. An effective inspection and regulation of the sale of these products is not that also provides more space for the advertising company e-cigarette manufacturers in covering only their positive effects. However, on consideration of Verkhovna Rada of Ukraine 22.04.2015 introduced draft Law of Ukraine "On amendments to some legislative acts of Ukraine concerning the distribution and advertising of electronic cigarettes" that should include restricting the sale of electronic cigarettes (including the prohibition of sales to minors) and the prohibition of advertising devices on Ukrainian territory.

Results of a review of the literature and of our own research allow us to draw the following conclusions:

1. Electronic cigarettes are actively used by the population; however, the level of knowledge about their effects is still low.

2. Despite the fact that they are sufficiently effective to reduce complaints related to smoking, their use as a tool of combating tobacco is not entirely justified.

3. For a full-fledged analysis, not only short-term, but also long-term studies of their main effects on the body are necessary.

\section{References}

[1] (2013) Socopros vyyavil v Ukraine 31\% kuril'schikov. [Social survey revealed $31 \%$ of smokers in Ukraine]. Zn.ua. Retrieved from: http:// zn.ua/UKRAINE/socopros-vyyavil-v-ukraine-31-kurilschikov-117450_. $\mathrm{html}$ [in Russian]

[2] Eshchenko, K. N., Zhadan, A. V., \& Shustval', N. F. (2013) Serdechno-sosudistaya sistema i kureniye [Cardiovascular system and smoking]. Har'kovskaya medicinskaya akademiya poslediplomnogo obrazovaniya, 4, 12-19. [in Russian].

[3] Mryha, I. A. (2015) Electronni syharety - Nova era pahubnoi zalezhnosti? [Electronic cigarettes - new era of addiction?]. Voxukraine. Retrieved from: http://voxukraine.org/2015/05/10/e-syharety/ [in Ukrainian]

[4] Charney, N. (2014)America's vaping revolution: How suspicious should we really be of the e-cigarette craze? Salon magazine, 7, 4.

[5] O'Leary, T., \& Laniel, S. (2008) Marketers of electronic cigarettes should halt unproved therapy claims. WHO media center. Retrieved from: http:// www.who.int/mediacentre/news/releases/2008/pr34/en/.

[6] Woessner, J. A. (2011) Historical Timeline of Electronic Cigarettes CASAA - The Consumer Advocates for Smoke-free Alternatives Association. Retrieved from: http://casaa.org/E-cigarette_History.html.

[7] (2014) Electronic cigarettes (e-cigarettes) dollar sales in the United States in 2014, by channel (in million U.S. dollars). The Statistics Portal. Retrieved from: http://www.statista.com/statistics/285074/use-cigarettes-dollar-sales-by-channel-2012/. 
[8] Fargo, W. (2015) The e-cigarette market. Tobacco Vapor Electronic Cigarette Association, 2, 1.

[9] Caponnetto, P., Campagna, D., Papale, G., Russo, C., \& Polosa, R. (2012) The emerging phenomenon of electronic cigarettes. Expert Review of Respiratory Medicine, 6, 63-74. doi: 10.1586/ ers.11.92.

[10] Weaver, M., Alison, B., Spindle, T., \& Eissenberg, T. (2014) Electronic Cigarettes. Journal of Addiction Medicine, 8, 234-240. doi: 10.1097/ ADM.0000000000000043.

[11] Bobko, O. O., \& Usata, V. Ya. (2011) Doslidzhennia vplyvu tiutiunopalinnia na orhanism studentiv VNTU [Investigation of the impact of smoking to the organism of VNTU students]. Zbirnyk naukovykh statei III Vseukrainskoho zizdu ekolohiv z mizhnarodnoiu uchastiu, 2, 706-709. [in Ukrainian].

[12] (2015) Diia electronnykh syharet na orhanism. Electronni syharety. [The impact of electronic cigarettes to the organism]. eCigTalk. Retrieved from: http://sygareta.com/diya-elektronnih-sigaret-na-organizm-elektronni-sigareti/ [in Ukrainian].

[13] de Andrade, M., Hastings, G., \& Angus, K. (2013) Promotion of electronic cigarettes: tobacco marketing reinvented. BMJ, 347, 7473. doi: 10.1136/bmj.f7473.

[14] King, B., Alam, S., Promoff, G., Arrazola, R., \& Dube, S. R. (2013) Awareness and ever use of electronic cigarettes among US adults 2010-2011. Nicotine Tob Res, 15(9), 1623-1627. doi: 10.1093/ntr/ ntt013.

[15] Etter, J., \& Bullen, C. (2014)A longitudinal study of electronic cigarette users. Addict Behav., 39, 491-494. doi: 10.1016/j.addbeh.2013.10.028.

[16] Bullen, C., Vickerman, K., Newcombe, R., \& Walker, N. (2013) Centers for Disease Control and Prevention. Notes from the field: electronic cigarette use among middle and high school students. Morb Mortal Wkly Rep., 62, 729-730.

[17] Leventhal, A. M., Strong, D. R., Kirkpatrick, M. G., Unger, J. B., Sussman, S., Riggs, N. R., et al. (2015) Association of Electronic Cigarette Use With Initiation of Combustible Tobacco Product Smoking in Early Adolescence. JAMA, 314, 700-707. doi: 10.1001/jama.2015.8950.

[18] Houston, T. (2013) Material Data Safety Sheet: Propylene Glycol. Sciencelab, 62, 1442-1445.

[19] Chen, S., Schweitzer, K., Law, S., Van Demark, M., Poirier, Ch., Justice, M. J. (2015) Endothelial disruptive pro-inflammatory effects of nicotine and e-cigarette vapor exposures. Am J Physiol Lung Cell Mol Physiol, 309, L175-L187. doi: 10.1152/ajplung.00411.2014.

[20] Sussan, T., Gajghate, S., Thimmulappa, R., Ma, J., Kim, J. H., Sudini, K., et al. (2015) Exposure to Electronic Cigarettes Impairs Pulmonary Anti-Bacterial and Anti-Viral Defenses in a Mouse Model. Plos One, 10(2), e0116861. doi: 10.1371/journal.pone.0116861.

[21] Czogała, J., Cholewiński, M., Kutek, A., \& Zielińska-Danch, W. (2012) Evaluation of changes in hemodynamic parameters after the use of electronic nicotine delivery systems among regular cigarette smokers. Przegl Lek., 69, 841-845.

[22] Swedeh, M., Oncken, C., \& Burki, N. (2014)Acute Effects Of Electronic Cigarettes On Airway Function In Human Subjects. Tobacco Control., 1, 178-185.

[23] Khan, M., \& Stanbrook, M. B. (2015) Efficacy And Safety Of Electronic Cigarettes For Smoking Cessation. Novel approaches to understand and improve health outcomes, 102, 182-187.

[24] Waters, J. (2015) E-cigarettes are just as addictive as the real thing and most are mislabeled, researchers warn. DailyMail. Retrieved from: http://www.dailymail.co.uk/sciencetech/article-3171371/E-cigarettesjust-addictive-real-thing-mislabeled-researchers-warn.html.

[25] Barbeau, A. M., Burda, J., \& Siegel, M. (2013) Perceived efficacy of e-cigarettes versus nicotine replacement therapy among successful e-cigarette users: a qualitative approach. Addictional Science Clin Pract, 8, 5. doi: 10.1186/1940-0640-8-5

[26] McRobbie, H., Bullen, C., Hartmann-Boyce, J., \& Hajek, P. (2014) Electronic cigarettes for smoking cessation and reduction. Cochrane Database Syst Rev., 12, CD010216. doi: 10.1002/14651858.CD010216.pub2.

[27] Rahman, M. A., Hann, N., Wilson, A., Mnatzaganian, G., \& Worrall-Carter, L. (2015) E-Cigarettes and Smoking Cessation: Evidence from a Systematic Review and Meta-Analysis. Plos One, 10(3), e0122544. doi: 10.1371 journal.pone. 0122544 .

[28] Waghel, R., Battise, D., Ducker, M. (2014) Effectiveness of Electronic Cigarettes as a Tool for Smoking Cessation or Reduction. Journ of Pharm techn, 31(1), 8-12. doi: 10.1177/8755122514547641.

\section{Information about author:}

Bogomolov A. Ye., MD, PhD, Associate Professor, Department of Phthisiatry with the Course of Clinical Immunology and Allergy, National Pirogov Memorial Medical University, Vinnytsia, Ukraine.

\section{Відомості про автора:}

Богомолов А. Є., канА. меА. наук, доцент каф. фтизіатрії з курсом клінічної імунології та алергології, Вінницький національний медичний університет імені М. І. Пирогова, Україна.

\section{Сведения об авторе:}

Богомолов А. Е., канА. меА. наук, Аоцент каф. фтизиатрии с курсом клинической иммунологии и аммергологии, Винницкий национальный медицинский университет имени Н. И. Пирогова, Украина.

Конфлікт інтересів: віАсутній.

Conflicts of Interest: author has no conflict of interest to declare.

Надійшла Ао редакції / Received: 22.11.2017

Після Аоопрацювання / Revised: 05.12.2017

Прийнято Ао Аруку / Accepted: 22.12.2017 